\title{
Is There Anything Left to be Told About John? The Future of Johannine Character Studies and the Literary Concept of Bildung
}

\author{
Teodor-Ioan Colda
}

\begin{abstract}
In this paper, the author suggests that Johannine scholarship can be enriched in the future with the contribution of scholars from different parts of the world, sometimes even from areas where Johannine scholarship does not have a long tradition. He also briefly advances a new approach to character studies in the Fourth Gospel, emphasizing the possibility of engaging the modern literary genre of Bildung/Bildungsroman in the study of the gospel narratives, succinctly arguing for the legitimacy of his approach. KEY WORDS: Fourth Gospel, characters, Bildung, Bildungsroman, novel.
\end{abstract}

$\mathrm{D}$ uring my Seminary years, I was encouraged by my professors to pursue an academic career in Johannine studies. The main reason was the fact that one could hardly find a New Testament scholar primarily focused on the Johannine track in the (Evangelical) Romanian theological context. I began to read John's Gospel with a higher level of interest than before. When the time to write my BA thesis came, I tried to find a subject that could be both scholarly and original. I decided to write on "The Theology of Exodus in the Fourth Gospel." I thought that my findings on Exodus in John were notable breakthroughs in Johannine scholarship. Little did I know at the beginning of my research that a considerable amount of material had been produced on the matter (not just for John's Gospel, ${ }^{1}$ but 
for all the other canonical gospels ${ }^{2}$ and that the Exodus/new Exodus theme was followed by many in different books of the Hebrew Bible ${ }^{3}$ and in the New Testament. $)^{4}$

Virtually the same situation occurred while writing my MTh dissertation, again in Johannine studies. I considered, probably inspired by one of Richard Bauckham's works, ${ }^{5}$ that a research in the politics of John's Gospel ${ }^{6}$ would be at least scholarly engaging if not somehow original. While completing my dissertation with the title "Towards a Political Theology of John's Gospel" I understood that I was mistaken again. ${ }^{7}$

One of my main issues was that in Romania, in a sense, all theology, besides Eastern-Orthodox theology (with its most influential theologian, the late Father Professor Dumitru Stăniloae, an acclaimed scholar in church dogmatics) ${ }^{8}$ can be considered in its adolescence, struggling to recover after a half of century of communism. Another issue is the fact that Eastern-Orthodox theologians, who represent the majority, are not very fond of biblical studies. ${ }^{9}$ So, Romanian theology really does not have a tradition in biblical research (besides occasional theologians that emerge from the Protestant tradition, such as Reverend Professor Hans Klein ${ }^{10}$ and sometimes from the Orthodox), though Evangelical theologians are struggling to raise an interest in this matter for the past three decades. ${ }^{11}$ But the main problem that any biblical student, researcher or scholar is facing in Romania is the lack of resources. Besides the rather small libraries held by the Seminaries of different Evangelical denominations (displaying on average 20000 volumes each), the library of a center for contemporary Christian education and culture (displaying around 38000 volumes) and the library of a private Evangelical Christian university (displaying over 60000 volumes), there is hardly any accomplished library for those who seek to do research in biblical studies. One must rely on resources that can be found abroad.

Hoping to avoid past experiences regarding writing a final thesis or dissertation, during the research for my doctoral degree (at the Baptist Theological Faculty, University of Bucharest), I managed to gather a considerable amount of resources in order to be able to produce a proper doctoral thesis. My periods of research in 
Cambridge (2012) and Oxford (2013-2014, as an academic visitor) proved to be very fruitful. But during all this time, I could not get myself free of a thought which a very good friend of mine and mentor shared once with me. When he understood that I was set on following the Johannine track he kindly asked me: "Is there anything left to be told about John?" (implying that there is already vast scholarship on John's Gospel). Ironically enough, he is an Old Testament scholar. I thought that I would fail again to produce something original from John. But while reading the Fourth Gospel, I suddenly noticed some details that could bring something forth, something I considered to be worth mentioning.

I realized that besides Jesus, who is undoubtedly the main character of the Fourth Gospel, as Culpepper correctly states, ${ }^{12}$ and, I must add, of any gospel, there are two very important figures that emerge through the gospel's narrative: Peter and the Beloved Disciple. I also noticed that the way in which the fourth evangelist ends his account is meant to bring for the last time the above mentioned characters into the spotlight. Bultmann skillfully emphasizes the role of the two disciples in chapter 21, arguing for a "motif of Peter and the beloved disciple."13 $\mathrm{T}$. Cottam also believes that the ending of the gospel tries to balance the narrative in which Peter denies Jesus, but also tries to dismiss a rumor regarding the Beloved Disciple. ${ }^{14}$ Blomberg carries the observations regarding the two even further. He believes that chapter 21 was added after Peter's death or possibly after the death of the Beloved Disciple..$^{15}$ This is a very significant conclusion because it shows the prominent roles of the two disciples for the Christian community that were familiar with the gospel's account and also the preeminent roles of the two for the primitive Christian community in Jerusalem. Blomberg is not the only one to observe that the last chapter of the Fourth Gospel is important because of Peter and the Beloved Disciple. D. A. Carson also states:

True, John 20:30-31 is the climax of the book, the 'conclusion' in that sense. But as in a 'whodunit' where all the pieces have finally come together in a magnificent act of disclosure, there remains certain authorial discretion: the book may 
end abruptly with the act of disclosure, the solution to the mystery, or it may wind down through a postscript that tells what happens to the characters, especially if what happens to them sheds a certain light backward onto the principal plot of the work. ${ }^{16}$

Based on these observations, I understood that at least the ending of the Fourth Gospel is about the outcome of the discipleship process of Peter and the Beloved Disciple. Also, the circular shape of the gospel, with Simon Peter's calling to follow Jesus at the beginning and a similar calling at the end reassured me that the observation was not misleading. ${ }^{17}$ But these considerations seemed not to be sufficient to develop a thesis focused on character studies in the Fourth Gospel, especially in the context in which this topic has been of major interest in Johannine studies for the past 30 years, ${ }^{18}$ starting with Culpepper's work (Anatomy of the Fourth Gospel) and even before that. ${ }^{19}$ Some scholars were interested in characters based on gender considerations; ${ }^{20}$ others were concerned with the anonymous characters, ${ }^{21}$ characters defined by ambiguity, ${ }^{22}$ minor characters $^{23}$ or non Jewish characters present in the narratives of the Fourth Gospel. ${ }^{24}$ In the same time some manifested interest for individual characters (the mother of Jesus, ${ }^{25}$ Nicodemus, ${ }^{26}$ the woman at the well, ${ }^{27}$ Moses, ${ }^{28}$ Judas, $^{29}$ the Jews, ${ }^{30}$ Martha and Mary, ${ }^{31}$ Lazarus, ${ }^{32}$ Mary Magdalene, ${ }^{33}$ Thomas, $^{34}$ Jesus $^{35}$ - and Logos ${ }^{36}$ - and $\operatorname{God}^{37}$ ), and others showed interest for characters in tandem ${ }^{38}$ or for the relationship between certain characters. ${ }^{39}$ There are some works concerned with Peter's portrayal ${ }^{40}$ and the portrayal of the Beloved Disciple $^{41}$ and even the portrayal of the two together. ${ }^{42}$

Like others, I became interested in the portrayals of Peter and the Beloved Disciple in the Fourth Gospel. But the same issue occurred. Is there anything left to be told about these characters in John? Then "the coin dropped." I recalled studying years ago about a modern literary concept that seemed to gather the details about the two disciples which I noticed in the Fourth Gospel. The concept I will be referring to is Bildung or Bildungsroman. The term is of German provenance and basically means "formation novel", referring to the development of the hero or the main character of the novel. ${ }^{43}$ 
Based on the way in which the image of a hero can be built, the novels can be classified as follows: a journey novel, a testing novel, a biographic or autobiographic novel and a Bildungsroman. ${ }^{44}$ Starting from the meaning of Bildung, R. P. Shaffner advances the idea of an 'apprenticeship' type of novel. ${ }^{45}$

Manfred Engel emphasizes a certain ambiguity of the term Bildungsroman, though it belongs to the tried and tested tools of literary criticism, there seems to be little consensus on its exact meaning. There are probably two reasons for this state of matters: the anachronistic origin of the term and its successful globalization. ${ }^{46}$ Most researches in the field agree that this genre appeared in German literature towards the end of the XVIII ${ }^{\text {th }}$ century with Christoph Martin Wieland's Deschichte des Aghaton in 1766-1767, Karl Philip Moritz's Anton Reiser in 1785-1790, as the first example of negative Bildungsroman, and Johann Wolfgang von Goethe's Wilhelm Meisters Lehrjahre in 1795-1796, as the seminal model of the genre. ${ }^{47}$ The term which adequately describes this type of novel would be created by Karl Morgenstern in 1810, using it for the first time in one of his lectures at the University of Tartu. ${ }^{48}$ Unfortunately his essays and lectures on the genre were little read and so his contribution was soon forgotten. Based on R. P. Shaffner's research it seems that the concept of Bildungsroman was already defined by Friedrich von Blankenburg towards the end of the XVIII ${ }^{\text {th }}$ century (in 1774) in his Versuch über den Roman. ${ }^{49}$ The term Bildungsroman was re-invented after a century from the above mentioned novels by the German philosopher Wilhelm Dilthey at the University of Berlin, who will use the term in Das Leben Schleiermachers in 1870. Yet the term didn't receive a broader reception until 1905 with the collection of essays Das Erlebnis und die Dichtung. ${ }^{50}$

According to Dithley, in a Bildungsroman the author follows the progress of a young man $^{51}$ in his struggle to understand himself, find his identity and establish his role and responsibility in society. Based on this view, a Bildungsroman has a universality which an autobiography doesn't have. The former follows a representative young man, who eventually becomes a type, and his experiences become symbols. ${ }^{52}$ 
But what is a Bildungsroman after all? The term received the following definition in the Oxford Dictionary of Literary Terms: "a kind of novel that follows the development of the hero from childhood or adolescence to adulthood, through a trouble quest for identity." ${ }^{3}$ Another definition is given by A Dictionary of Literary Terms and Literary Theory: "this is a term more or less synonymous with Erziehungsroman-literally an upbringing or education novel. ... Widely used by German critiques, it refers to a novel which is an account of the youthful development of a hero or heroine (usually the former.) It describes the process by which maturity is achieved by through the various ups and downs of life." ${ }^{54}$

It seemed that Peter and the Beloved Disciple fit in the generous limits of the Bildung/Bildungsroman genre. But is it safe to mingle with a modern literary concept, when in fact we are dealing with the ancient text of the Fourth Gospel and its characters? The main inconvenience is probably in the largely spread understanding among scholars that ancient literary characters are quite different from the modern ones. This objection is due to the noticeable difference in which a character is understood in the Mediterranean ancient literature and the European modern literature. Ancient characters are viewed merely as types, while modern characters are expected to show noticeable psychological development. ${ }^{55}$ But one should be aware, as S. P. Roth points out, that the difference between ancient and modern characterization is one of kind, and not one of quality. ${ }^{56}$ Despite these observations, some scholars seemed to identify the Bildung/Bildungsroman genre in different Bible narratives.

Professor J. Barton, considering J. Miles' proposal that the Old Testament should be regarded as a novel with a single plot and with a progressive portrayal of its main character, God, ${ }^{57}$ suggested that the entire Old Testament could be viewed as a Bildungsroman. ${ }^{58}$ This kind of observation encourages the Bible reader to identify without much difficulty numerous narratives which reflect the Bildung/Bildungsroman genre. For example in the Pentateuch: the life of Joseph, ${ }^{59}$ but also the life of Jacob, the life of Moses, the life of Joshua; or outside the Pentateuch: Samson, Samuel, and David, ${ }^{60}$ even Esther ${ }^{61}$ or Job, ${ }^{62}$ and probably Daniel too. ${ }^{63}$ All these stories 
with their main protagonists reveal more or less specific elements of a Bildungsroman.

Interestingly, R. Romøren argues that the intrinsic model of Bildungsroman has in fact a biblical origin:

All histories become narratives in one way or another, and in this case the narrative conforms to the pattern of Bildungsroman, with its narrative structure Home-DepartureAdventure and Trials-Homecoming. The important part here is the idea of the return home, which I regard as a pre-modern and religious concept of story, with roots going back to the Bible (The Prodigal Son). ${ }^{64}$

Again, the element emphasized by Romøren, "the return home", can be easily found in the last episode of the Fourth Gospel, especially in Peter's case. For Simon Peter this is not just the moment of returning home, but the moment when he reaches his maturity after important trials and hardship. A. J. Köstenberger reaches similar conclusions in a discussion regarding the mission of Jesus' disciples. He states that the development of Peter and the Beloved Disciple is followed through the gospel narratives culminating with the scene from 21:15-23. Moreover, the relationship between the two disciples provides a coherent perspective for the entire gospel. ${ }^{65}$

Being aware of the popularity and the realism which are characterizing the Bildung genre and also acknowledging the fact that "the term Bildungsroman has enormous range and applicability,"66 I decided to write a doctoral thesis with the title: "An Ancient Bildung Based on Pentateuch Narratives. The Portrait of Peter and of the Beloved Disciple in the Fourth Gospel." Though a Bildungsroman is interested in just one character, I realized that, in a sense, Peter and the Beloved Disciple are inseparable and they are brought forth together in major moments of the plot (see John 13, probably 18, $20,21){ }^{67}$

Everything seemed safe enough in terms of research until I encountered some of R. R. Beck's observations in the context of a rather brief interaction he had with the Bildungsroman genre. Referring to the way in which a modern reader approaches an 
ancient text, Beck believes that the reader needs a tool of control to be assisted by while aiming to understand the ancient text, because he naturally approaches the text using a genre more familiar to him. This tool of control is in fact the ancient genre which characterizes the text itself. He also specifies that the first century genres act as second-order controls, because we primarily tend to read the text in our own terms, appealing to the genres which are culturally and temporarily closer to us. If used properly, the second-order controls might rule out some current options, offering as an example the Bildungsroman, because this genre is lacking in early precedents, adding that this is not the case of biography. At the same time, ancient genres might suggest modern analogues. ${ }^{68}$

Though Beck's observations prove to be pertinent, they could be somehow refined. It is true that historically, the Bildungsroman lacks early precedents, but it might have considerable aesthetic and conceptual precedents as already briefly shown above. An ancient text, like Mark's Gospel to which Beck was referring to, or like John's Gospel, can display characteristics specific to the Bildungsroman genre, despite the ancient author's independence in relation to the history of the modern genre itself. So to speak, Beck's conclusion is not definitive, because even the romantic novelists who created Bildungsromane have done this before the time when a proper terminology to describe the phenomena would appear. ${ }^{69}$

At the same time, there is the other side of the discussion. B. Hochman, for example, is aware of the differences between ancient and modern literature in different ways (to indicate just one, the way in which the person is understood), but at the end, as modern readers, he argues that "we have no alternative but to construct our images of character in terms of our knowledge and experience."70 $\mathrm{M}$. Stibbe is even more specific, saying that one can use "the techniques associated with characterization in the modern novel", while approaching the characters of the Fourth Gospel. ${ }^{71}$

I would like to advance, in sense, a slightly new approach in Johannine character studies. Probably it could be beneficial to give the modern reader more credit and more independence while approaching the ancient text of gospel, especially in the context of the discussion about Bildung and the characters of the Fourth Gospel. 
Using "second-order controls" - to make use of Beck's phrase - is scholarly sane, but what if we try to approach the text in a more appealing fashion to the modern reader? Instead of dismissing the Bildungrsroman because of its presupposed lack of precedents, one could benefit from the aesthetics of a very common genre even for the Bible narratives.

Being aware of the fact that my intervention merely scratches the surface of the discussion advertised in the title of my paper, I would like to add at the end that besides the lack of resource in some parts of the world and the scholarly abundance in other parts, it seems that Johannine scholarship is still flourishing and continually gathering new topics in its swirl. So there is still plenty left to be told about John.

\section{NOTES}

${ }^{1}$ For example, J. J. Enz, "The Book of Exodus as a Literary Type for the Gospel of John," Journal for Biblical Literature 76 (1957): 208-215; R. H. Smith, "Exodus Typology in the Fourth Gospel," Journal for Biblical Literature 81 (1962): 329-42; Duncan J. Derrett, "Why and How Jesus Walked on the Sea?," Novum Testamentum 23.4 (1981): 330-48; John Dominic Crossan, "It Is Written: A Structuralist Analysis of John 6," Semeia 26 (1983): 3-21; John Ashton, "The Identity and Function of the Ioudaioi in the Fourth Gospel," Novum Testamentum 27 (1985): 40-75; Stephen J. Casselli, "Jesus as Escathological Torah," Theological Studies 18.1 (1997): 15-41; Adam C. English, "Feeding Imagery in the Gospel of John: Uniting the Physical and the Spiritual," Perspectives in Religious Studies 28.3 (Fall 2001): 203-14; Stan Harstine, Moses as a Character in the Fourth Gospel: A Study of Ancient Reading Techniques (Journal for the Study of the New Testament Supplement Series 229; Sheffield: Sheffield Academic Press, 2002); Andrew C. Brunson, Psalm 118 in the Gospel of John: An Intertextual Study on the New Exodus Pattern in the Theology of John (Tübingen: Mohr Siebeck, 2003); Susan Hylen, Allusion and Meaning in John 6 (Berlin; New York: Walter de Gruyter, 2005).

${ }^{2}$ For example, Mánek Jindrich, "New Exodus [of Jesus] in the Book of Luke," Novum Testamentum 2.1 (1957): 8-23; James T. Dennison, Jr., "The Exodus: Historical Narrative, Prophetic Hope, Gospel Fulfillment", Presbyterion 8.2 (1982): 1-12; Sharon H. Ringe, "Luke 9:28-36: The Begining of an Exodus," Semeia 28 (1983): 83-99.

${ }^{3}$ For example, David Daube, The Exodus Pattern in the Bible (All Souls Studies 2; London: Faber \& Faber, 1963); Susan Gillingham, "The Exodus Tradition and Israelite Psalmody," Scottlish Journal of Theology 52.1 (1999): 
19-46; Melody, D. Knowels, "Pilgrimage Imagery in the Returns in Ezra," Journal for Biblical Literature 123.1 (2004): 57-74; Anthony R. Ceresko, "The Rhetorical Strategy of the Fourth Servant Song (Isaiah 53:13-53:12): Poetry and the Exodus-New Exodus," Catholic Biblical Quarterly 56 (1994): 42-55.

${ }^{4}$ For example, Otto A. Piper, "Unchanging Promises: Exodus in the New Testament," Interpretation 11.1 (1957): 3-22; Fred L. Fisher, "The New and Greater Exodus: The Exodus Pattern in the New Testament," SWJT 20 (1977): 69-79; R. E. Nixon, The Exodus in the New Testament (London: Tyndale, 1963); J. Richard Clifford, S.J., "The Exodus in the Christian Bible: The Case for 'Figural' Reading," Theological Studies 63.2 (2002): 345-61.

5 Richard Bauckham, The Bible in Politics (Louisville, Kentucky: Westminster/John Knox Press, 1989).

${ }^{6}$ See Warren Carter,John and Empire (New York, London: T\&T Clark, 2008); Travis D. Trost, Who Should be King in Israel? A Study on Roman Imperial Politics, the Dead Sea Scrolls, and the Fourth Gospel (New York: Peter Lang, 2010); Beth M. Stovell, Mapping Metaphorical Discourse in the Fourth Gospel. John's Eternal King (Linguistic Biblical Studies 5; Leiden: Brill, 2012).

${ }^{7}$ A important study, in this respect, was produced by David Rensberger, Johannine Faith and Liberating Community (Philadelphia, Pennsylvania: The Westminster Press, 1988).

${ }^{8}$ See Dumitru Stăniloae, Theology and the Church (Crestwood, NY: St Vladimir's Seminary Press, 1980); IDEM, The Experience of God. Orthodox Dogmatic Theology. Vol. 1. Revelation and Knowledge of the Triune God, trans. ed. Ioan Ionita \& Robert Barringer (Brookline, MA: Holy Cross Orthodox Press, 1994); IDEM, The Experience of God. Orthodox Dogmatic Theology. Vol. 2.The World: Creation and Deification, trans. ed. Ioan Ionita \& Robert Barringer (Brookline, MA: Holy Cross Orthodox Press, 2000); ); IDEM, The Experience of God. Orthodox Dogmatic Theology. Vol. 3.The Person of Jesus Christ as God and Savior, trans. ed. Ioan Ionita \& Robert Barringer (Brookline, MA: Holy Cross Orthodox Press, 2011); IDEM, The Experience of God. Orthodox Dogmatic Theology. Vol. 4.The Church: Communion in the Holy Spirit, trans. ed. Ioan Ionita \& Robert Barringer (Brookline, MA: Holy Cross Orthodox Press, 2012); IDEM, The Experience of God. Orthodox Dogmatic Theology. Vol. 5.The Sanctifying Mysteries, trans. ed. Ioan Ionita \& Robert Barringer (Brookline, MA: Holy Cross Orthodox Press, 2012); IDEM, The Experience of God. Orthodox Dogmatic Theology. Vol. 6.The Fulfillment of Creation, trans. ed. Ioan Ionita \& Robert Barringer (Brookline, MA: Holy Cross Orthodox Press, 2013); IDEM, The Holy Trinity: In the Beginning There Was Love (Brookline, MA: Holy Cross Orthodox Press, 2013).

${ }^{9}$ As Trine Stauning Willert asserts, referring to Greek Orthodox theology, "the preference given to patristic studies has resulted in a poor contemporary tradition of biblical studies." New Voices in Greek Orthodox Thought. Untying the bond between Nation and Religion (Ashgate New Critical Thinking in Religion, Theology and Biblical Studies Series; Surrey, UK/Burlington, VT: Ashgate, 2014), 
67.

${ }^{10}$ See Hans Klein, Leben neu entdecken. Entwurf einer Biblischen Theologie (Stuttgart: 1991); IDEM, Bewährung im Glauben: Studien zum Sondergut des Evangelisten Matthäus (Biblisch-Theologische Studien, 26; NeukirchenVluyn: Neukirchener, 1996); IDEM, Lukasstudien (Forschugen zu Religion und Literatur des Alten und Neuen Testaments, 209; Göttingen: Vandenhoeck \& Ruprecht, 2005).

${ }^{11}$ Most of the Romanian Evangelical scholars who managed to pursue a doctoral degree abroad were mainly interested in biblical studies: Alexandru Neagoe, The Trial of the Gospel: An Apologetic Reading of Luke's Trial Narratives (Cambridge, UK; New York: Cambridge University Press, 2002); Radu Gheorghita, The Role of the Septuagint in Hebrews: An Investigation of Its Influence with Special Consideration to the use of Hab 2:3-4in Heb 10:37-38 (Tübingen: Mohr Siebeck, 2003); Sorin Sabou, Between Horror and Hope: Paul's Metaphysical Language of Death in Romans 6:1-11 (Paternoster Biblical Monographs; Bletchley: Paternoster, 2005); Octavian D. Baban, On the Road Encounters in LukeActs: Hellenistic Mimesis and Luke's Theology of the Way (Paternoster Biblical Monographs; Miltin Keynes: Paternoster, 2006); Corneliu Constantineanu, The Social Significance of Reconciliation in Paul's Theology: Narrative Readings in Romans (Library of New Testament Studies; London: T\&T Clark, 2010); John Tipei, "The Laying on of the Hands in the New Testament" (PhD Dissertation, University of Sheffield, 2000); Dorin Axente, "Light and Darkness in the Fourth Gospel: A Missiological Reading of the Johannine Dualism" (PhD Dissertation, London School of Theology/Brunel University, 2005); Silviu Tatu, "The Qatal// Yiqtol (Yiqtol//Qatal) Verbal Sequence in Couplets in the Hebrew Psalter with Special Reference to Ugaritic Poetry: a Case Study in Systemic Functional Grammar" (PhD Dissertation, Oxford Center for Mission Studies and University of Wales, 2006); Marcel Valentin Măcelaru, "From Divine Speech to National/ Ethnic Self-Definition in the Hebrew Bible: Representation(s) of Identity and the Motif of Divine-Human Distancing in Israel's Story" (DPhil Dissertation, University of Oxford, 2008). Others have shown interest in Stăniloae's work: Emil Bartos, Deification in Eastern Orthodox Theology: An Evaluation and Critique of the Theology of Dumitru Stăniloae (Carlisle, Cumbria: Paternoster Press, 1999); Danut Manastireanu, A Perichoretic Model of the Church: The Trinitarian Ecclesiology of Dumitru Staniloae (Saarbrücken: Lambert Academic Publishing, 2012).

${ }^{12}$ R. Alan Culpepper, Anatomy of the Fourth Gospel (Philadelphia: Fortress Press, 1988), 106.

${ }^{13}$ Rudolf Bultmann, The Gospel of John: A Commentary (Oxford: Basil Blackwell, 1971), 704.

${ }^{14}$ Thomas Cottam, The Fourth Gospel Rearranged (London: Epworth Press, 1952), 76-77.

${ }^{15}$ Craig L. Blomberg, The Historical Reliability of John's Gospel (Downers Grove, Illinois: Inter-Varsity Press, 2001), 39, 44. 
${ }^{16}$ D. A. Carson, The Gospel According to John (Leicester, England, InterVarsity Press; Grand Rapids, Michigan: William B. Eerdmans Publishing Company, 1991), 666.

17 Peter J. Williams in "Not the Prologue of John," Journal for the Study of the New Testament 33 (2011): 375-86, shows that in the Fourth Gospel there are multiple beginnings and multiple endings.

${ }^{18}$ For example Raymond F. Collins, These Things Have Been Written: Studies on the Fourth Gospel (Louvain Theological and Pastoral Monographs, 2; Louvain: Peeters Press, 1990): 1-45; Peter Dschulnigg, Jesus Begegnen: Personen und ihre Bedeutung im Johannesevangelium (Münster: Lit, 2002); Cornelis Bennema, Encountering Jesus. Character Studies in the Fourth Gospel (Milton Keynes; Colorado Springs; Hyderabad: Paternoster, 2009); Nicolas Farelly, The Disciples in the Fourth Gospel: A Narrative Analysis of their Faith and Understanding (Tübingen: Mohr Siebeck, 2010); Steven A. Hunt, D. Francois Tolmie \& Ruben Zimmermann, Character Studies in the Fourth Gospel (Tübingen: Mohr Siebeck, 2013).

${ }^{19}$ For example E. Kraft, “Die Personen des Johannesevangeliums," EvT 16 (1956): 18-32.

${ }^{20}$ Robert G. Maccini, Her Testimony is True: Women Witnesses according to John (Journal for the Study of the New Testament Supplement Series 125; Sheffield: Sheffield Academic Press, 1996); Jo-Ann A. Brant, "Husband Hunting: Characterization and Narrative Art in the Gospel of John," Biblical Interpretation 4 (1996): 205-23; Adeline Fehribach, The Women in the Life of the Bridegroom: A Feminist Historical-Literary Analysis of the Female Characters in the Fourth Gospel (Collegeville, Minnesota: The Liturgical Press, 1998); Ingrid R. Kitzberger, ed., Transformative Encounters: Jesus and Women Re-viewed (Leiden: Brill, 1999), 77-111; Colleen M. Conway, Men and Women in the Fourth Gospel: Gender and Johannine Characterization (Society of Biblical Literature Dissertation Series 167; Atlanta, Georgia: Society of Biblical Literature, 1999); Margaret M. Beirne, Women and Men in the Fourth Gospel: A genuine Discipleship of Equals (London: Sheffield Academic Press, 2003).

${ }^{21}$ David R. Beck, The Discipleship Paradigm: Readers and Anonymous Characters in the Fourth Gospel (Biblical Interpretation Series 27; Leiden; New York; Köln: Brill, 1997).

${ }^{22}$ Susan E. Hylen, Imperfect Believers: Ambiguous Characters in the Gospel of John (Louisville, Kentucky: Westminster John Knox Press, 2009).

${ }^{23}$ For example, Colleen M. Conway, "Speaking through Ambiguity: Minor Characters in the Fourth Gospel," Biblical Interpretation 10 (2002): 324-41.

${ }^{24}$ Elizabeth Danna, "Which Side of the Line? A Study of the Characterization of non-Jewish Characters in the Gospel of John" (PhD Dissertation, University of Durham, 1997).

${ }^{25}$ Judith M. Lieu, "The Mother of the Son in the Fourth Gospel," Journal for Biblical Literature 117 (1998): 61-77.

${ }^{26}$ M. Bassler, "Mixed Signals: Nicodemus in the Fourth Gospel," Journal for 
Biblical Literature 108 (1989): 635-46.

${ }^{27}$ Frances Taylor Gench, Back to the Well: Women's Encounters with Jesus in the Gospels (Louisville: Westminster John Knox Press, 2004), 109-35.

${ }^{28}$ Harstine, Moses as a Character in the Fourth Gospel.

${ }^{29}$ Tom Thatcher, "Jesus, Judas and Peter: Character by Contrast in the Fourth Gospel," Bibliotheca Sacra 153 (1996): 435-48; Michael W. Martin, Judas and the Rhetoric of Comparison in the Fourth Gospel (New Testament Monographs 25; Sheffield: Sheffield Phoenix Press, 2010).

${ }^{30}$ Francis J. Moloney, "The Jews' in the Fourth Gospel: Another Perspective," Pac 15 (2002):16-36.

${ }^{31}$ Francis J. Moloney, "The Faith of Mary and Martha: A Narrative Approach to John 11.17-40," Biblica 75 (1994): 471-93.

${ }^{32}$ Wilhem Wuellner, "Putting Life Back into the Lazarus Story and Its Reading: The Narrative Rhetoric of John 11 as the Narration of Faith," Semeia 53 (1991): 114-32.

${ }^{33}$ Susanne Ruschmann, Maria von Magdala im Johannesevangelium: Jüngerin-Zeugin-Lebensbotin (Münster: Aschendorff, 2002); Reinhard Nordsieck, Maria Magdalena, Die Frau An Jesu Seite (Berlin: Lit, 2014).

${ }^{34}$ Dennis Sylva, Thomas - Love as Strong as Death: Faith and Commitment in the Fourth Gospel (London: T\&T Clark Bloomsbury, 2013).

${ }^{35}$ Pierre Létourneau, "La caractérisation de Jésu dans l'Évangile de Jean: Stratégie narrative et acte de lecture " in Et vous, qui dites-vous que je suis? La question des personnages dans les récits bibliques, ed. Pierre Létourneau, Michel Talbot (Sciences Bibliques 16; Montréal, QC: Médiaspaul, 2006): 143-72.

${ }^{36}$ Jason Sturdevant, The Character of Jesus in the Fourth Gospel: The Adaptability of the Logos (PhD Dissertation; Princeton Theological Seminary, 2013). On 'Logos' see Ioan-Gheorghe Rotaru, "Logosul şi înțelepciunea," in Studii de istorie a filosofiei universale, XIII, edited by Alexandru Boboc, N. I. Mariş (București: Editura Academiei Române, 2005), 295-323.

${ }^{37}$ Marianne Meye Thompson, "'God's Voise You Have Never Heard, God's Form You Have Never Seen:' The Characterization of God in the Gospel of John," Semeia 63 (1993): 177-204.

${ }^{38}$ Christopher M. Skinner, John and Thomas - Gospels in Conflict? Johannine Characterization and the Thomas Question (Princeton Theological Monograph Series 115; Eugene, OR: Pickwick Publications, 2009).

${ }^{39}$ Judith Hartenstein, Charakterisierung im Dialog: Maria Magdalena, Petrus, Thomas und die Mutter Jesu im Johannesevangelium (Göttingen/Fribourg: Vandenvoeck \& Ruprecht/Academic Press Fribourg, 2007).

${ }^{40}$ Bradford B. Blaine, Jr., Peter in the Gospel of John: The Making of an Authentic Disciple (Society of Biblical Literature Academia Biblica 27; Leiden/Boston: Brill, 2007); Donald Chung-Yiu Leung, "Peter in the Fourth Gospel: Character Development and Reader Emphaty" (PhD Dissertation, Dallas Theological Seminary, 2001); Tanja Schultheiss, Das Petrusbild im 
Johannesevangelium (Tübingen: Mohr Siebeck, 2012).

${ }^{41}$ Thorlwald Lorenzen, Der Lieblingsjünger im Johannesevangelium: Eine redaktionsgeschichtliche Studie (Stuttgart Bibelstudien 55; Stuttgart: KBW Verlang, 1971); Joseph A. Grassi, The Secret Identity of the Beloved Disciple (New York/Mahwah: Paulist Press, 1992); James H. Charlesworth, The Beloved Disciple: Whose Witness Validates the Gospel of John? (Valley Forge, Pennsylvania: Trinity Press International, 1995); Adele Reinhartz, Befriending the Beloved Disciple: A Jewish Reading of the Gospel of John (New York, NY/London: Continuum, 2001); Ismo Dunderberg, The Beloved Disciple in Conflict? Revisiting the Gospels of John and Thomas (Oxford: Oxford University Press, 2006).

42 Gerald Webb Broomfield, M.A., John, Peter and the Fourth Gospel (London: Society for Promoting Christian Knowledge, 1934); Lutz Simon, Petrus und derLieblingsjünger im Johannesevangelium: Amt und Autorität (Europäische Hochschulschriften, Reihe XXIII, Theologie; Frankfurt am Main: Peter Lang, 1994); Kevin Quast, Peter and the Beloved Disciple: Figures of a Community in Crisis (Journal for the Study of the New Testament Supplement Series 32; Sheffield: Journal for the Study of the Old Testament Press/Sheffield Academic Press, 1989).

${ }^{43}$ Giovanna Summerfield \& Lisa Downward, New Perpectives on the European Bildungsroman (London/New York: Continuum, 2010), 1.

${ }^{44}$ Mikhail Mikhailovich Bakhtin, Speech, Genre and other Late Essays (Austin, Texas: University of Texas Press, 2004), 10.

${ }^{45}$ Randolph P. Shaffner, The Apprenticeship Novel (New York: Peter Lang, 1984), 3.

${ }^{46}$ Manfred Engel, "Variants of the Romantic 'Bildungsroman'” in Romantic Prose Fiction, ed. Gerald Gillespie, Manfred Engel \& Bernard Dieterle (Amsterdam, Philadelphia: John Benjamins, 2008), 263.

${ }^{47}$ Engel, "Variants of the Romantic 'Bildungsroman'”.

${ }^{48}$ Engel, "Variants of the Romantic 'Bildungsroman'".

${ }^{49}$ Shaffner, The Apprenticeship Novel, 3.

${ }^{50}$ Engel, "Variants of the Romantic 'Bildungsroman'”, 263.

${ }^{51} \mathrm{G}$ Summerfield \& L. Downward observe that for some Bildungsroman critiques society is receptive for male development alone. New Perpectives..., 170.

${ }^{52}$ Summerfield \& Downward, New Perpectives..., 1.

${ }^{53}$ Chris Baldick, Oxford Dictionary of literary Terms (Oxford: Oxford University Press, 2008), 35.

54 J. A. Cuddon, A Dictionary of Literary Terms and Literary Theory (Chichester: Wiley-Blackwell, 2013).

${ }^{55}$ As Bennema points out, scholars did not reach a consensus regarding the differences between ancient and modern characterization techniques and if they could be used simultaneously. Bennema, Encountering Jesus, 11.

56 "The difference has to do with the distinction between characterization that is representational and characterization that is illustrative, a distinction that 
is well known in literary circles." S. John Roth, The Blind the Lame and the Poor: Character Types in Luke-Acts (Sheffield: Sheffield Academic Press, 1997), 77.

${ }^{57}$ Jack Miles, God: A Biography (New York: Alfred A. Knopf, 1995).

${ }^{58}$ John Barton, The Old Testament: Canon, Literature and Theology (Society for the Old Testament Study Series; Aldershot, Hampshire: Ashgate Publishing, 2007), 182.

${ }^{59}$ Robert R. Robinson, "Patriarchal Narrative" in The Encyclopedia of Christianity, vol. 4 (Brand Rapids, Michigan/Leiden: Willaim B. Eerdmans/Brill, 2005), 95-96.

${ }^{60}$ Professor Robert P. Gordon considers that the narrative known as the 'History of David's Rise from 2 Samuel 24-26 "merits the description as a Bildungsroman." Hebrew Bible and Ancient Versions (Society for the Old Testament Study Series; Aldershot, Hampshire: Ashgate Publishing, 2006), xx. In the same order of ideas R. Alter notices that Shakespeare was able " to invent a kind of Bildungsroman for the young Prince Hal" (the young king Henry the Vth), starting with a series of hints of historical tradition, and a similar method can be identified in the portrayal of King David too. Robert Alter, The Art of Biblical Narrative (New York: Basic Books, 1981), 40-41.

${ }^{61}$ Susan Niditch, "Interpreting Esther: Categories, Contexts and Interpretive Ambiguities" in The Writings and Later Wisdom Books, ed. Christl M. Maier \& Nuria Calduch-Benages (Atlanta, GA: SBL Press, 2014), 263.

${ }^{62}$ Carl A. Newson argues that the Book of Job can be seen as ", a kind of Bildungsroman for the reader's moral imagination." The Book of Job; A Contest of Moral Imagination (Oxford: Oxford University Press, 2003), 17-21.

${ }^{63}$ Newson understands "the slow and painful moral development of Nebuchadnezzar in Daniel 1-4 has something of a Bildungsroman. Newson, Job, 47. See also Carl A. Nelson, "God's Other: The Intractable Problem of the Gentile King in Judean and Early Jewish Literature" in The 'Other' in Second Temple Judaism. Essays in Honor of John J. Collins, ed. Daniel C. Harlow, Karina Martin Hogan, Matthew Goff, Joel S. Kaminsky (Grand Rapids, Michigan/Cambridge, UK: William B. Eerdmans Publishing Company, 2011), 47.

${ }^{64}$ Rolf Romøren, "From Literary Text to Literary Field: Boys' Fiction in Norway between the Two World Wars: a Re-reading" in The Presence of the Past in Children's Literature, ed. Ann Lawson Lucas (Westport, CT: Praeger Publishers, 2003), 18.

${ }^{65}$ Andreas J. Köstenberger, The Missions of Jesus and the Disciples according to the Fourth Gospel (Grand Rapids, Michigan: Wm. B. Eerdmans Publishing Co., 1998), 154-60.

${ }^{66}$ Neil Easterbrook, "Bildungsroman" in The Greenwood Encyclopedia of Science Fiction and Fantasy, ed. Gary Westhafl (Westport, CT: Greenwood Press, 2005), 1: 81.

${ }^{67}$ It is not uncommon to study characters in tandem. For example see Beirne, Women and Men.

${ }^{68}$ Robert R. Beck, Nonviolent Story: Narrative Conflict Resolution in the 
Gospel of Mark (Eugene, OR: Wipf and Stock Publishers, 2008), 29.

${ }^{69}$ Engel, „Bildungsroman,” 264.

${ }^{70}$ Baruch Hochman, Character in Literature (Ithaca, N. Y.: Cornell University Press, 1985), 56. See also William H. Shepherd, The Narrative Function of the Holy Spirit as a Character in Luke-Acts (Society of Biblical Literature Dissertation Series, 147; Atlanta: Scholars Press, 1994), 50.

${ }^{71}$ Mark Stibbe, "Telling the Father's Story: The Gospel of John as Narrative Theology" in Challenging Perspectives on the Gospel of John, ed. John Lierman (Tübingen: Mohr Siebeck, 2006), 173.

\section{Bibliography}

Alter, Robert. The Art of Biblical Narrative. New York: Basic Books, 1981. Ashton, John. "The Identity and Function of the Ioudaioi in the Fourth Gospel." Novum Testamentum 27 (1985): 40-75.

Axente, Dorin. "Light and Darkness in the Fourth Gospel: A Missiological Reading of the Johannine Dualism." PhD Dissertation, London School of Theology/ Brunel University, 2005.

Baban, Octavian D. On the Road Encounters in Luke-Acts: Hellenistic Mimesis and Luke's Theology of the Way. Paternoster Biblical Monographs; Miltin Keynes: Paternoster, 2006.

Bakhtin, Mikhail Mikhailovich. Speech, Genre and other Late Essays. Austin, Texas: University of Texas Press, 2004.

Baldick, Chris. Oxford Dictionary of literary Terms. Oxford: Oxford University Press, 2008.

Barton, John. The Old Testament: Canon, Literature and Theology. Society for the Old Testament Study Series; Aldershot, Hampshire: Ashgate Publishing, 2007.

Bartos, Emil. Deification in Eastern Orthodox Theology: An Evaluation and Critique of the Theology of Dumitru Stăniloae. Carlisle, Cumbria: Paternoster Press, 1999.

Bassler, M. "Mixed Signals: Nicodemus in the Fourth Gospel." Journal for Biblical Literature 108 (1989): 635-46.

Bauckham, Richard. The Bible in Politics. Louisville, Kentucky: Westminster/ John Knox Press, 1989.

Beck, David R. The Discipleship Paradigm: Readers and Anonymous Characters in the Fourth Gospel. Biblical Interpretation Series 27; Leiden; New York; Köln: Brill, 1997.

Beck, Robert R. Nonviolent Story: Narrative Conflict Resolution in the Gospel of Mark. Eugene, OR: Wipf and Stock Publishers, 2008.

Beirne, Margaret M. Women and Men in the Fourth Gospel: A genuine Discipleship of Equals. London: Sheffield Academic Press, 2003. 
Bennema, Cornelis. Encountering Jesus. Character Studies in the Fourth Gospel. Milton Keynes; Colorado Springs; Hyderabad: Paternoster, 2009.

Blaine, Bradford B., Jr. Peter in the Gospel of John: The Making of an Authentic Disciple. Society of Biblical Literature Academia Biblica 27; Leiden/Boston: Brill, 2007.

Blomberg, Craig L. The Historical Reliability ofJohn's Gospel. Downers Grove, Illinois: Inter-Varsity Press, 2001.

Brant, Jo-Ann A. "Husband Hunting: Characterization and Narrative Art in the Gospel of John." Biblical Interpretation 4 (1996): 205-23.

Broomfield, Gerald Webb, M.A. John, Peter and the Fourth Gospel. London: Society for Promoting Christian Knowledge, 1934.

Brunson, Andrew C. Psalm 118 in the Gospel of John: An Intertextual Study on the New Exodus Pattern in the Theology of John. Tübingen: Mohr Siebeck, 2003.

Bultmann, Rudolf. The Gospel of John: A Commentary. Oxford: Basil Blackwell, 1971.

Carson, D. A. The Gospel According to John. Leicester, England, Inter-Varsity Press; Grand Rapids, Michigan: William B. Eerdmans Publishing Company, 1991.

Carter, Warren. John and Empire. New York, London: T\&T Clark, 2008.

Casselli, Stephen J. "Jesus as Escathological Torah." Theological Studies 18.1 (1997): 15-41.

Ceresko, Anthony R. "The Rhetorical Strategy of the Fourth Servant Song (Isaiah 53:13-53:12): Poetry and the Exodus-New Exodus." Catholic Biblical Quarterly 56 (1994): 42-55.

Charlesworth, James H. The Beloved Disciple: Whose Witness Validates the Gospel of John? Valley Forge, Pennsylvania: Trinity Press International, 1995.

Clifford, J. Richard, S.J., "The Exodus in the Christian Bible: The Case for 'Figural' Reading," Theological Studies 63.2 (2002): 345-61.

Collins, Raymond F. These Things Have Been Written: Studies on the Fourth Gospel. Louvain Theological and Pastoral Monographs, 2; Louvain: Peeters Press, 1990.

Constantineanu, Corneliu. The Social Significance of Reconciliation in Paul's Theology: Narrative Readings in Romans . Library of New Testament Studies; London: T\&T Clark, 2010.

Conway, Colleen M. Men and Women in the Fourth Gospel: Gender and Johannine Characterization. Society of Biblical Literature Dissertation Series 167; Atlanta, Georgia: Society of Biblical Literature, 1999.

. "Speaking through Ambiguity: Minor Characters in the Fourth

Gospel." Biblical Interpretation 10 (2002): 324-41.

Cottam, Thomas. The Fourth Gospel Rearranged. London: Epworth Press, 1952.

Crossan, John Dominic. "It Is Written: A Structuralist Analysis of John 6." Semeia 26 (1983): 3-21. 
Cuddon, J. A. A Dictionary of Literary Terms and Literary Theory. Chichester: Wiley-Blackwell, 2013.

Culpepper, R. Alan. Anatomy of the Fourth Gospel. Philadelphia: Fortress Press, 1988.

Danna, Elizabeth. "Which Side of the Line? A Study of the Characterization of non-Jewish Characters in the Gospel of John." PhD Dissertation, University of Durham, 1997.

Daube, David. The Exodus Pattern in the Bible. All Souls Studies 2; London: Faber \& Faber, 1963.

Dennison, James T., Jr. "The Exodus: Historical Narrative, Prophetic Hope, Gospel Fulfillment", Presbyterion 8.2 (1982): 1-12.

Derrett, Duncan J. "Why and How Jesus Walked on the Sea?" Novum Testamentum 23.4 (1981): 330-48. English, Adam C. "Feeding Imagery in the Gospel of John: Uniting the Physical and the Spiritual," Perspectives in Religious Studies 28.3 (Fall 2001): 203-14.

Dschulnigg, Peter. Jesus Begegnen: Personen und ihre Bedeutung im Johannesevangelium. Münster: Lit, 2002.

Dunderberg, Ismo. The Beloved Disciple in Conflict? Revisiting the Gospels of John and Thomas. Oxford: Oxford University Press, 2006.

Easterbrook, Neil. "Bildungsroman." In The Greenwood Encyclopedia of Science Fiction and Fantasy, edited by Gary Westhafl. Westport, CT: Greenwood Press, 2005.

Engel, Manfred. "Variants of the Romantic 'Bildungsroman!'” In Romantic Prose Fiction, edited by Gerald Gillespie, Manfred Engel \& Bernard Dieterle. Amsterdam, Philadelphia: John Benjamins, 2008.

Enz, J. J. "The Book of Exodus as a Literary Type for the Gospel of John." Journal for Biblical Literature 76 (1957): 208-2015.

Farelly, Nicolas. The Disciples in the Fourth Gospel: A Narrative Analysis of their Faith and Understanding . Tübingen: Mohr Siebeck, 2010.

Fehribach, Adeline. The Women in the Life of the Bridegroom: A Feminist Historical-Literary Analysis of the Female Characters in the Fourth Gospel. Collegeville, Minnesota: The Liturgical Press, 1998.

Fisher, Fred L. "The New and Greater Exodus: The Exodus Pattern in the New Testament." SWJT 20 (1977): 69-79.

Gench, Frances Taylor. Back to the Well: Women's Encounters with Jesus in the Gospels. Louisville: Westminster John Knox Press, 2004.

Gheorghita, Radu. The Role of the Septuagint in Hebrews: An Investigation of Its Influence with Special Consideration to the use of Hab 2:3-4in Heb 10:37-38. Tübingen: Mohr Siebeck, 2003.

Gillingham, Susan. "The Exodus Tradition and Israelite Psalmody." Scottlish Journal of Theology 52.1 (1999): 19-46.

Gordon, Robert P. Hebrew Bible and Ancient Versions. Society for the Old Testament Study Series; Aldershot, Hampshire: Ashgate Publishing, 2006.

Grassi, Joseph A. The Secret Identity of the Beloved Disciple. New York/ 
Mahwah: Paulist Press, 1992.

Harstine, Stan. Moses as a Character in the Fourth Gospel: A Study of Ancient Reading Techniques. Journal for the Study of the New Testament Supplement Series 229; Sheffield: Sheffield Academic Press, 2002.

Hartenstein, Judith. Charakterisierung im Dialog: Maria Magdalena, Petrus, Thomas und die Mutter Jesu im Johannesevangelium. Göttingen/Fribourg: Vandenvoeck \& Ruprecht/Academic Press Fribourg, 2007.

Hochman, Baruch. Character in Literature. Ithaca, N. Y.: Cornell University Press, 1985.

Hunt, Steven A. and D. Francois Tolmie, Ruben Zimmermann. Character Studies in the Fourth Gospel. Tübingen: Mohr Siebeck, 2013.

Hylen, Susan. Allusion and Meaning in John 6. Berlin; New York: Walter de Gruyter, 2005.

. Imperfect Believers: Ambiguous Characters in the Gospel of John.

Louisville, Kentucky: Westminster John Knox Press, 2009.

Jindrich, Mánek. "New Exodus [of Jesus] in the Book of Luke." Novum Testamentum 2.1 (1957): 8-23.

Kitzberger, Ingrid R., ed. Transformative Encounters: Jesus and Women Reviewed. Leiden: Brill, 1999.

Klein, Hans. Leben neu entdecken. Entwurf einer Biblischen Theologie. Stuttgart: 1991.

. Bewährung im Glauben: Studien zum Sondergut des Evangelisten Matthäus. Biblisch-Theologische Studien, 26; NeukirchenVluyn: Neukirchener, 1996.

. Lukasstudien. Forschugen zu Religion und Literatur des Alten und Neuen Testaments, 209; Göttingen: Vandenhoeck \& Ruprecht, 2005.

Köstenberger, Andreas J. The Missions of Jesus and the Disciples according to the Fourth Gospel. Grand Rapids, Michigan: Wm. B. Eerdmans Publishing Co., 1998.

Kraft, E. “Die Personen des Johannesevangeliums." EvT 16 (1956): 18-32.

Létourneau, Pierre. "La caractérisation de Jésu dans l'Évangile de Jean: Stratégie narrative et acte de lecture." In Et vous, qui dites-vous que je suis? La question des personnages dans les récits bibliques, edited by Pierre Létourneau, Michel Talbot, 143-72. Sciences Bibliques 16; Montréal, QC: Médiaspaul, 2006.

Leung, Donald Chung-Yiu. "Peter in the Fourth Gospel: Character Development and Reader Emphaty." PhD Dissertation, Dallas Theological Seminary, 2001.

Lieu, Judith M. "The Mother of the Son in the Fourth Gospel." Journal for Biblical Literature 117 (1998): 61-77.

Lorenzen, Thorlwald. Der Lieblingsjünger im Johannesevangelium: Eine redaktionsgeschichtliche Studie. Stuttgart Bibelstudien 55; Stuttgart: KBW Verlang, 1971.

Maccini, Robert G. Her Testimony is True: Women Witnesses according to John. Journal for the Study of the New Testament Supplement Series 125; 
Sheffield: Sheffield Academic Press, 1996.

Manastireanu, Danut. A Perichoretic Model of the Church: The Trinitarian Ecclesiology of Dumitru Staniloae. Saarbrücken: Lambert Academic Publishing, 2012.

Martin, Michael W. Judas and the Rhetoric of Comparison in the Fourth Gospel. New Testament Monographs 25; Sheffield: Sheffield Phoenix Press, 2010.

Măcelaru, Marcel Valentin. "From Divine Speech to National/Ethnic SelfDefinition in the Hebrew Bible: Representation(s) of Identity and the Motif of Divine-Human Distancing in Israel's Story." DPhil Dissertation, University of Oxford, 2008.

Melody, D. Knowels, "Pilgrimage Imagery in the Returns in Ezra," Journal for Biblical Literature 123.1 (2004): 57-74.

Miles, Jack. God: A Biography. New York: Alfred A. Knopf, 1995.

Moloney, Francis J. "The Faith of Mary and Martha: A Narrative Approach to John 11.17-40." Biblica 75 (1994): 471-93.

(2002):16-36.

"'The Jews' in the Fourth Gospel: Another Perspective." Pac 15

Neagoe, Alexandru. The Trial of the Gospel: An Apologetic Reading of Luke's Trial Narratives. Cambridge, UK; New York: Cambridge University Press, 2002.

Newson, Carl A. The Book of Job; A Contest of Moral Imagination . Oxford: Oxford University Press, 2003.

"God's Other: The Intractable Problem of the Gentile King in Judean and Early Jewish Literature." In The 'Other' in Second Temple Judaism. Essays in Honor of John J. Collins, edited by Daniel C. Harlow, Karina Martin Hogan, Matthew Goff, Joel S. Kaminsky. Grand Rapids, Michigan/Cambridge, UK: William B. Eerdmans Publishing Company, 2011.

Niditch, Susan. "Interpreting Esther: Categories, Contexts and Interpretive Ambiguities." In The Writings and Later Wisdom Books, edited by Christl M. Maier \& Nuria Calduch-Benages. Atlanta, GA: SBL Press, 2014.

Nixon, R. E. The Exodus in the New Testament. London: Tyndale, 1963.

Nordsieck, Reinhard. Maria Magdalena, Die Frau An Jesu Seite. Berlin: Lit, 2014.

Piper, Otto A. "Unchanging Promises: Exodus in the New Testament," Interpretation 11.1 (1957): 3-22.

Quast, Kevin. Peter and the Beloved Disciple: Figures of a Community in Crisis. Journal for the Study of the New Testament Supplement Series 32; Sheffield: Journal for the Study of the Old Testament Press/Sheffield Academic Press, 1989.

Reinhartz, Adele. Befriending the Beloved Disciple: A Jewish Reading of the Gospel of John . New York, NY/London: Continuum, 2001.

Rensberger, David.Johannine Faithand Liberating Community.Philadelphia, Pennsylvania: The Westminster Press, 1988.

Ringe, Sharon H. "Luke 9:28-36: The Begining of an Exodus." Semeia 28 
(1983): 83-99.

Robinson, Robert R. "Patriarchal Narrative" in The Encyclopedia of Christianity, vol. 4. Brand Rapids, Michigan/Leiden: Willaim B. Eerdmans/Brill, 2005.

Romøren, Rolf. "From Literary Text to Literary Field: Boys' Fiction in Norway between the Two World Wars: a Re-reading." In The Presence of the Past in Children's Literature, edited by Ann Lawson Lucas. Westport, CT: Praeger Publishers, 2003.

Rotaru, Ioan-Gheorghe."Logosul şi înțelepciunea." In Studii de istorie a filosofiei universale, XIII, edited by Alexandru Boboc, N.I.Mariş. Bucureşti: Editura Academiei Române, 2005.

Roth, S. John. The Blind the Lame and the Poor: Character Types in LukeActs. Sheffield: Sheffield Academic Press, 1997.

Ruschmann, Susanne. Maria von Magdala im Johannesevangelium:Jüngerin - Zeugin - Lebensbotin. Münster: Aschendorff, 2002.

Sabou, Sorin. Between Horror and Hope: Paul's Metaphysical Language of Death in Romans6:1-11. Paternoster Biblical Monographs; Bletchley: Paternoster, 2005.

Schultheiss, Tanja. Das Petrusbild im Johannesevangelium. Tübingen: Mohr Siebeck, 2012. 1984.

Shaffner, Randolph P. The Apprenticeship Novel. New York: Peter Lang,

Shepherd, William H. The Narrative Function of the Holy Spirit as a Character in Luke-Acts. Society of Biblical Literature Dissertation Series, 147; Atlanta: Scholars Press, 1994.

Simon, Lutz. Petrus und derLieblingsjünger im Johannesevangelium: Amt und Autorität. Europäische Hochschulschriften, Reihe XXIII, Theologie; Frankfurt am Main: Peter Lang, 1994.

Skinner, Christopher M. John and Thomas - Gospels in Conflict? Johannine Characterization and the Thomas Question. Princeton Theological Monograph Series 115; Eugene, OR: Pickwick Publications, 2009.

Smith, R. H. "Exodus Typology in the Fourth Gospel." Journal for Biblical Literature 81 (1962): 329-42.

Stăniloae, Dumitru. Theology and the Church. Crestwood, NY: St Vladimir's Seminary Press, 1980.

. The Experience of God. Orthodox Dogmatic Theology. Vol. 1. Revelation and Knowledge of the Triune God, trans. ed. Ioan Ionita \& Robert Barringer. Brookline, MA: Holy Cross Orthodox Press, 1994.

The Experience of God. Orthodox Dogmatic Theology. Vol. 2.The World: Creation and Deification, trans. ed. Ioan Ionita \& Robert Barringer. Brookline, MA: Holy Cross Orthodox Press, 2000.

The Experience of God. Orthodox Dogmatic Theology. Vol. 3.The

Person of Jesus Christ as God and Savior, trans. ed. Ioan Ionita \& Robert Barringer. Brookline, MA: Holy Cross Orthodox Press, 2011. 
The Experience of God. Orthodox Dogmatic Theology. Vol. 4.The Church: Communion in the Holy Spirit, trans. ed. Ioan Ionita \& Robert Barringer. Brookline, MA: Holy Cross Orthodox Press, 2012.

The Experience of God. Orthodox Dogmatic Theology. Vol. 5.The Sanctifying Mysteries, trans. ed. Ioan Ionita \& Robert Barringer. Brookline, MA: Holy Cross Orthodox Press, 2012.

The Experience of God. Orthodox Dogmatic Theology. Vol. 6.The Fulfillment of Creation, trans. ed. Ioan Ionita \& Robert Barringer. Brookline, MA: Holy Cross Orthodox Press, 2013).

The Holy Trinity: In the Beginning There Was Love. Brookline, MA: Holy Cross Orthodox Press, 2013.

Stovell, Beth M. Mapping Metaphorical Discourse in the Fourth Gospel. John's Eternal King. Linguistic Biblical Studies 5; Leiden: Brill, 2012.

Sturdevant, Jason. The Character of Jesus in the Fourth Gospel: The Adaptability of the Logos. PhD Dissertation, Princeton Theological Seminary, 2013.

Summerfield, Giovanna and Lisa Downward. New Perpectives on the European Bildungsroman. London/New York: Continuum, 2010.

Stibbe, Mark. "Telling the Father's Story: The Gospel of John as Narrative Theology." In Challenging Perspectives on the Gospel of John, edited by John Lierman. Tübingen: Mohr Siebeck, 2006.

Sylva, Dennis. Thomas - Love as Strong as Death: Faith and Commitment in the Fourth Gospel. London: T\&T Clark Bloomsbury, 2013.

Tatu, Silviu. "The Qatal//Yiqtol (Yiqtol//Qatal) Verbal Sequence in Couplets in the Hebrew Psalter with Special Reference to Ugaritic Poetry: a Case Study in Systemic Functional Grammar." PhD Dissertation, Oxford Center for Mission Studies and University of Wales, 2006.

Thatcher, Tom. "Jesus, Judas and Peter: Character by Contrast in the Fourth Gospel." Bibliotheca Sacra 153 (1996): 435-48.

Thompson, Marianne Meye. "'God's Voise You Have Never Heard, God's Form You Have Never Seen:' The Characterization of God in the Gospel of John." Semeia 63 (1993): 177-204.

Tipei, John. "The Laying on of the Hands in the New Testament." PhD Dissertation, University of Sheffield, 2000.

Trost, Travis D. Who Should be King in Israel? A Study on Roman Imperial Politics, the Dead Sea Scrolls, and the Fourth Gospel. New York: Peter Lang, 2010.

Williams, Peter J. "Not the Prologue of John." Journal for the Study of the New Testament 33 (2011): 375-86.

Wuellner, Wilhem. "Putting Life Back into the Lazarus Story and Its Reading: The Narrative Rhetoric of John 11 as the Narration of Faith." Semeia 53 (1991): 114-32.

Willert, Trine Stauning. New Voices in Greek Orthodox Thought. Untying the bond between Nation and Religion. Ashgate New Critical Thinking in Religion, Theology and Biblical Studies Series; Surrey, UK/Burlington, VT: Ashgate, 2014. 